\title{
Short Communication: First record of the cassava lace bug Vatiga illudens (Drake, 1922) (Hemiptera: Heteroptera: Tingidae) from East Java, Indonesia
}

\author{
RETNO DYAH PUSPITARINI ${ }^{1, \vartheta}$, ITO FERNANDO ${ }^{1}$, YOGO SETIAWAN ${ }^{1}$, DEWI ANGGRAINI ${ }^{2}$, \\ HAMMAM ABDULLAH RIZQI ${ }^{3}$ \\ ${ }^{1}$ Department of Plant Pests and Diseases, Faculty of Agriculture, Universitas Brawijaya. Jl. Veteran, Malang 65145, East Java, Indonesia. \\ Tel.: +62-341-575843, ve-mails: retnodyah@ub.ac.id \\ ${ }^{2}$ Plant Protection Technical Implementation Unit of Food and Horticultural Crops of East Java, Jl. Pagesangan II No.58, Surabaya, 60233, East Java, \\ Indonesia \\ ${ }^{3}$ Department of Agriculture and Food of Blitar. Jl. Ahmad Yani No. 25, Sananwetan, Blitar, 66137, East Java, Indonesia
}

Manuscript received: 5 June 2021. Revision accepted: 23 June 2021.

\begin{abstract}
Puspitarini RD, Fernando I, Setiawan Y, Anggraini D, Rizqi HA. 2021. Short Communication: First record of the cassava lace bug Vatiga illudens (Drake, 1922) (Hemiptera: Heteroptera: Tingidae) from East Java, Indonesia. Biodiversitas 22: 2870-2876. The cassava lace bug, Vatiga illudens (Drake, 1922) (Hemiptera: Heteroptera: Tingidae) is recorded from Indonesia for the first time. This species is found on the abaxial surface of leaves of cassava (Manihot esculenta Crantz, Euphorbiaceae) in several plantations of East Java and heavily infest this plant. Vatiga illudens is native to the Neotropical Region and seems to be the alien species in the Oriental Region. This tingid has already spread over a wide region of East Java, suggesting that the invasion of the lace bug endangers the other regions cultivating cassava.
\end{abstract}

Keywords: Alien species, invasion, Manihot esculenta, neotropical region, oriental region

\section{INTRODUCTION}

During our field investigation of spider mite infestation on cassava (Manihot esculenta Crantz, Euphorbiaceae) plantations (Puspitarini et al. 2021), serendipitously, we found an indeterminate species of lace bugs (Hemiptera: Heteroptera: Tingidae) living on the lower leaf surface. Approximately 150 to 200 individuals per leaf were observed. Lace bugs or tingids can be easily distinguished by the lace-like appearance of the dorsum (Du and Yao 2018; Cho et al. 2020; Schuh and Weirauch 2020). The other diagnostic characters of the family as follows: the absence of ocelli; a well-developed bucculae; antenna with four segments, in which, the segments I and II are stout (short and thick) but the segment III is slender and usually very long; the tarsi are two-segmented; and the hemelytra is not divided into clavus, corium, and membrane (Stonedahl et al. 1992; Guilbert 2001; Schuh and Weirauch 2020).

All lace bugs are herbivorous however they exhibit a high degree of host specificity (Schuh and Weirauch 2020), and the majority being either oligophagous or monophagous (Drake and Ruhoff 1965; Guidoti et al. 2015). As a result, tingids are unable to establish themselves in areas where their hosts are unavailable (Souma and Kamitani 2021). According to Stonedahl et al. (1992), most of the lace bugs feeding on cassava belong to Vatiga Drake \& Hambleton (Tinginae: Tingini). Currently, five species have been known, namely $V$. cassia (Drake and Hambleton 1934), V. illudens (Drake 1922), V. manihotae (Drake 1922), V. pauxillae (Drake and Poor 1939), and $V$. varianta (Drake 1930). All of them are native to the Neotropical Region (Froeschner 1993). The two most economically important species are $V$. illudens and $V$. manihotae, both are known as "cassava lace bugs" (CLB) (Bellon et al. 2012; dos Santos et al. 2019). Although native to the Neotropical Region, Vatiga species are expected to invade other tropical cassava-producing countries when seedlings are transported, especially countries in Southeast Asia (Montemayor et al. 2015). In 2010, another Neotropical cassava pest Phenacoccus manihoti Marile-Ferrero (Hemiptera: Pseudococcidae), was inadvertently introduced from South America into Indonesia, causing significant economic damage to the country (Muniappan et al. 2009; Fanani et al. 2019). As a result, Indonesia should anticipate or be prepared for the invasion of CLB.

In Indonesia, no CLB infestations have been reported so far. Even the book "The Pests of Crops in Indonesia" did not mention the occurrence of CLB (Kalshoven 1981). According to the cassava pest list written by the Indonesian Agency for Agricultural Research and Development, CLB has been absent in Indonesia (Saleh et al. 2013). Similarly, the annual data of field inspections in East Java maintained by the Plant Protection Technical Implementation Unit of Food and Horticultural Crops, validated that the occurrence of CLB is not documented (personal communication). Moreover, in Indonesia, CLB is also not considered a quarantine pest (Ministry of Agriculture of Indonesia 2020). Based on external anatomical features, we identified 
the collected CLB as V. illudens. Therefore, this study serves as the first record of this species in Indonesia. The introduction of $V$. illudens raises concerns about its invasion and potential as a new exotic cassava pest in Indonesia. Furthermore, we discussed our expectations for future research to prevent the pest's spread and mitigate its outbreak.

\section{MATERIALS AND METHODS}

Surveys were conducted at the beginning of March 2021 on twenty-three cassava plantations located across East Java, Indonesia, but the majority were located in Malang. Purposive sampling was used as the sampling method. On each plantation, leaves with necrotic spots or yellowing symptoms were harvested and kept on a plastic bag. The sampled leaves were then placed on a cool box to maintain their freshness. The number of leaves taken on each plantation was not strictly determined. In the laboratory, the leaves were placed at $4^{\circ} \mathrm{c}$ for 60 minutes so that the insects became inactive, easing the observation.

The obtained lace bugs were observed under a portable digital microscope (Dino-Lite, AM4113/AD4113 series). Some specimens were preserved in $70 \%$ ethanol and will be sent to Museum Zoologicum Bogoriense (Cibinong, West Java, Indonesia). The adults were identified to genera level based on Stonedahl et al. (1992) and Guidoti et al. (2015), and to species level based on Froeschner (1993). For the measurement, ten individuals of each life stage were randomly selected, and their images were captured with the microscope at a given magnification. The resulting images were used for the morphometric measurements by using the Dino-Lite 2.0 as the software. The body length of nymphs was measured from the tip of the clypeus (apex of the head) to the tip of the abdominal tergite nine (apex of the abdomen), whereas the body length of adults was measured from the apex of the head to the apex of the hemelytron. The maximum body width of nymphs and adults was measured across mesothoracic wing pad and hemelytron, respectively.

Geographic coordinates of the surveyed locations were obtained from Google Maps. SimpleMappr was used to create the distribution map of the cassava lace bugs (Shorthouse 2010; Souma 2020). The terminology used in this current study follows that of Drake and Ruhoff (1965).

\section{RESULTS AND DISCUSSION}

\section{Occurrence of the cassava lace bug on the surveyed locations and the damage it caused on the cassava plants}

The occurrence of CLB was confirmed in Malang, Pasuruan, Blitar, Mojokerto, and Probolingo (Table 1, Figure 1). However, the introduction pathway of CLB to East Java is still unknown. It is evident from its abundance that this pest has been present in the affected areas for several months or years. Hence, additional field investigations are urgently needed, especially on the main cassava-producing cities other than Malang, such as Tuban, Ponorogo, Pacitan, Trenggalek, and Madura Island. CLB has not yet moved to far-western (Ngawi) and eastern (Jember, Bondowoso, and Banyuwangi) East Java from this preliminary result. Considering that cassava is one of the main food crops in Indonesia, the invasion of CLB may become a "ticking bomb". CLB has wreaked havoc on cassava crops across its native regions, resulting in significant harvest losses. Currently, CLB has been introduced outside its native range. Well-established populations of CLB have been reported in Florida, USA (Halbert 2010) and the Réunion Islands, Africa (Streito et al. 2012). On the other hand, Montemayor et al. (2015) projected that CLB would spread to other tropical areas, and the invasion is based on bioclimatic characteristics and the abundance of cassava plantations. According to their findings, all Southeast Asian countries are favorable areas for CLB, and so are highly vulnerable to infestation.

CLB feeds on the abaxial surface of cassava leaves (Figure 2A). The bugs did not fly when touched but instead escaped by walked away. Guidoti et al. (2015) mentioned that tingids mostly live gregariously and have sedentary habits, in which they are recognizable by a low flight activity. The observed CLB seems to have a preference for the lower and middle leaves since the bug densities observed in young leaves are relatively lower. It has been known that the initial colonization of CLB begins on the undersides of basal and middle leaves of the cassava, however, when its population is high, the bugs will crawl to the apical leaves (Bellotti et al. 2012). The infested cassava plants showed yellowish necrotic spots on the surveyed locations, which later become reddish-brown (Figure 2B). The mildly injured leaf was still green in appearance, whereas the severely injured leaf evolved completely to yellow shades. These observed symptoms are in agreement with the previous study reports (Bellotti et al. 1999). Furthermore, Bellon et al. (2012) stated that these injuries will decrease the plant's photosynthesis capacity and cause premature defoliation of the leaves.

\section{Identification and the external anatomy of the cassava lace bug}

Based on the morphological examination, the collected CLB from East Java was identified as Vatiga illudens. All of the materials examined in the present study well match the following diagnostic characters of $V$. illudens provided by the previous study (cf. Froeschner 1993): head with a pair of frontal spines (sometimes lacking one of pairs), without median spine (Figure 3A-C); antennal segment I as long as head; and costal area of hemelytron with two rows of areolae without apex throughout its length (Figure 3D). Additionally, all of the Indonesian specimens well match the original description of V. illudens (Drake 1922). 
Table 1. Localities, districts, geographic coordinates, number of sampled leaves, and the occurrence of the cassava lace bug

\begin{tabular}{|c|c|c|c|c|}
\hline Localities & Districts & Coordinates & No. sampled leaves & Cassava lace bug \\
\hline \multirow[t]{9}{*}{ Malang } & Blimbing, Purwodadi & $7^{\circ} 56^{\prime} 1.95^{\prime \prime} \mathrm{S}, 112^{\circ} 38^{\prime} 41.71^{\prime \prime} \mathrm{E}$ & 15 & + \\
\hline & Blimbing, Pandanwangi & $7^{\circ} 57^{\prime} 27.86^{\prime \prime} \mathrm{S}, 112^{\circ} 39^{\prime} 48.25^{\prime \prime} \mathrm{E}$ & 10 & + \\
\hline & Lowokwaru & $7^{\circ} 56^{\prime} 24.11^{\prime \prime} \mathrm{S}, 112^{\circ} 36^{\prime} 56.77^{\prime \prime} \mathrm{E}$ & 10 & + \\
\hline & Lawang & $7^{\circ} 49^{\prime} 50.3^{\prime \prime} \mathrm{S}, 112^{\circ} 41^{\prime} 19.66^{\prime \prime} \mathrm{E}$ & 15 & \\
\hline & Pakis & $7^{\circ} 59^{\prime} 22.12^{\prime \prime} \mathrm{S}, 112^{\circ} 42^{\prime} 53.11^{\prime \prime} \mathrm{E}$ & 10 & + \\
\hline & Tumpang & $8^{\circ} 0^{\prime} 12.1^{\prime \prime} \mathrm{S}, 112^{\circ} 44^{\prime} 17.66^{\prime \prime} \mathrm{E}$ & 20 & - \\
\hline & Poncokusumo & $8^{\circ} 2^{\prime} 56.5^{\prime \prime} \mathrm{S}, 112^{\circ} 48^{\prime} 57.3^{\prime \prime} \mathrm{E}$ & 10 & - \\
\hline & Turen & $8^{\circ} 8^{\prime} 59.51^{\prime \prime} \mathrm{S}, 112^{\circ} 41^{\prime} 39.6^{\prime \prime}$ & 20 & + \\
\hline & Bantur & $8^{\circ} 20^{\prime} 12.56^{\prime \prime} \mathrm{S}, 112^{\circ} 32^{\prime} 9.09^{\prime \prime} \mathrm{E}$ & 20 & - \\
\hline \multirow[t]{3}{*}{ Pasuruan } & Gondang Wetan & $7^{\circ} 42^{\prime} 38.39^{\prime \prime} \mathrm{S}, 112^{\circ} 55^{\prime} 28.47^{\prime \prime} \mathrm{E}$ & 15 & - \\
\hline & Sukorejo & $7^{\circ} 41^{\prime} 5.14^{\prime \prime} \mathrm{S}, 112^{\circ} 42^{\prime} 31.83^{\prime \prime} \mathrm{E}$ & 15 & + \\
\hline & Pandaan & $7^{\circ} 39^{\prime} 8.1^{\prime \prime} \mathrm{S}, 112^{\circ} 41^{\prime} 26.71^{\prime \prime} \mathrm{E}$ & 15 & + \\
\hline \multirow[t]{3}{*}{ Blitar } & Kademangan & $8^{\circ} 12^{\prime} 39.2^{\prime \prime} \mathrm{S}, 112^{\circ} 6^{\prime} 17.21^{\prime \prime} \mathrm{E}$ & 15 & + \\
\hline & Kesamben & $8^{\circ} 6^{\prime} 25.7^{\prime \prime} \mathrm{S}, 112^{\circ} 23^{\prime} 27.92^{\prime \prime}$ & 20 & + \\
\hline & Selopuro & $8^{\circ} 7^{\prime} 48.9^{\prime \prime} \mathrm{S}, 112^{\circ} 20^{\prime} 26.45^{\prime \prime} \mathrm{E}$ & 20 & + \\
\hline Kediri & Mojo & $7^{\circ} 50^{\prime} 58.4^{\prime \prime} \mathrm{S}, 111^{\circ} 28^{\prime} 0.28^{\prime \prime} \mathrm{E}$ & 10 & - \\
\hline Mojokerto & Mojoanyar & $7^{\circ} 50^{\prime} 58.4^{\prime \prime} \mathrm{S}, 111^{\circ} 28^{\prime} 0.28^{\prime \prime} \mathrm{E}$ & 20 & + \\
\hline Probolinggo & Wonoasih & $7^{\circ} 29^{\prime} 41.1^{\prime \prime} \mathrm{S}, 112^{\circ} 27^{\prime} 24.2^{\prime \prime} \mathrm{E}$ & 20 & + \\
\hline Ngawi & Karangjati & $7^{\circ} 26^{\prime} 32.39^{\prime \prime} \mathrm{S}, 111^{\circ} 36^{\prime} 55.56^{\prime \prime} \mathrm{E}$ & 20 & - \\
\hline Tulungagung & Ngantru & $7^{\circ} 58^{\prime} 09.3^{\prime \prime} \mathrm{S}, 111^{\circ} 55^{\prime} 34.0^{\prime \prime} \mathrm{E}$ & 10 & - \\
\hline Jember & Ambulu & $8^{\circ} 21^{\prime} 37.78^{\prime \prime} \mathrm{S}, 113^{\circ} 38^{\prime} 17.71^{\prime \prime} \mathrm{E}$ & 20 & - \\
\hline Bondowoso & Tlogosari & $7^{\circ} 59^{\prime} 37.31^{\prime \prime} \mathrm{S}, 113^{\circ} 55^{\prime} 28.78^{\prime \prime} \mathrm{E}$ & 10 & - \\
\hline Banyuwangi & Sempu & $8^{\circ} 18^{\prime} 27.81^{\prime \prime} \mathrm{S}, 114^{\circ} 12^{\prime} 5.82^{\prime \prime} \mathrm{E}$ & 15 & - \\
\hline
\end{tabular}

Note: $+/$ - denote the occurrence and the absence of the cassava lace bug, respectively

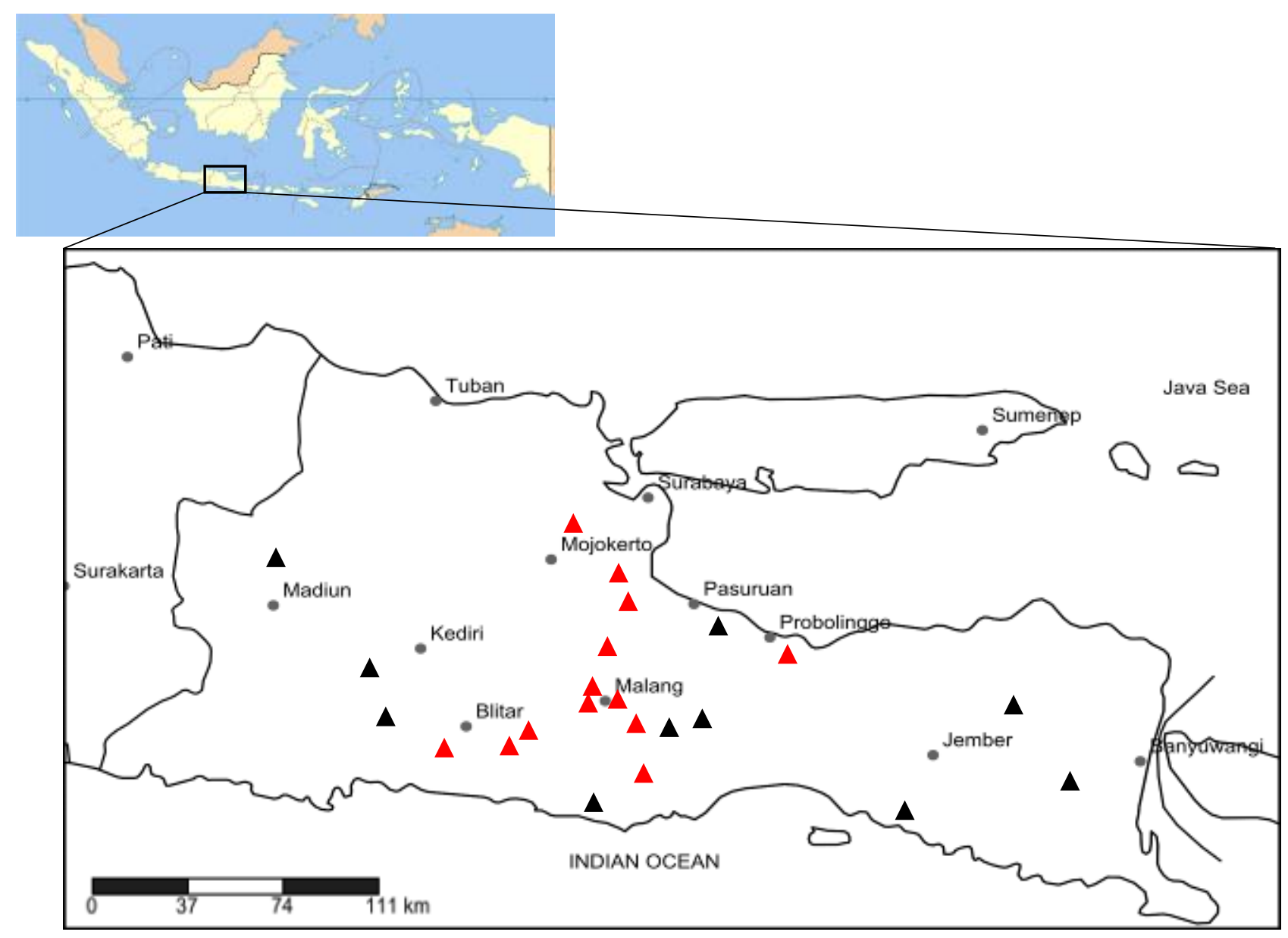

Figure 1. Distribution map of the cassava lace bug found in East Java, Indonesia (red and black icons denote the occurrence and the absence of the cassava lace bug, respectively) 

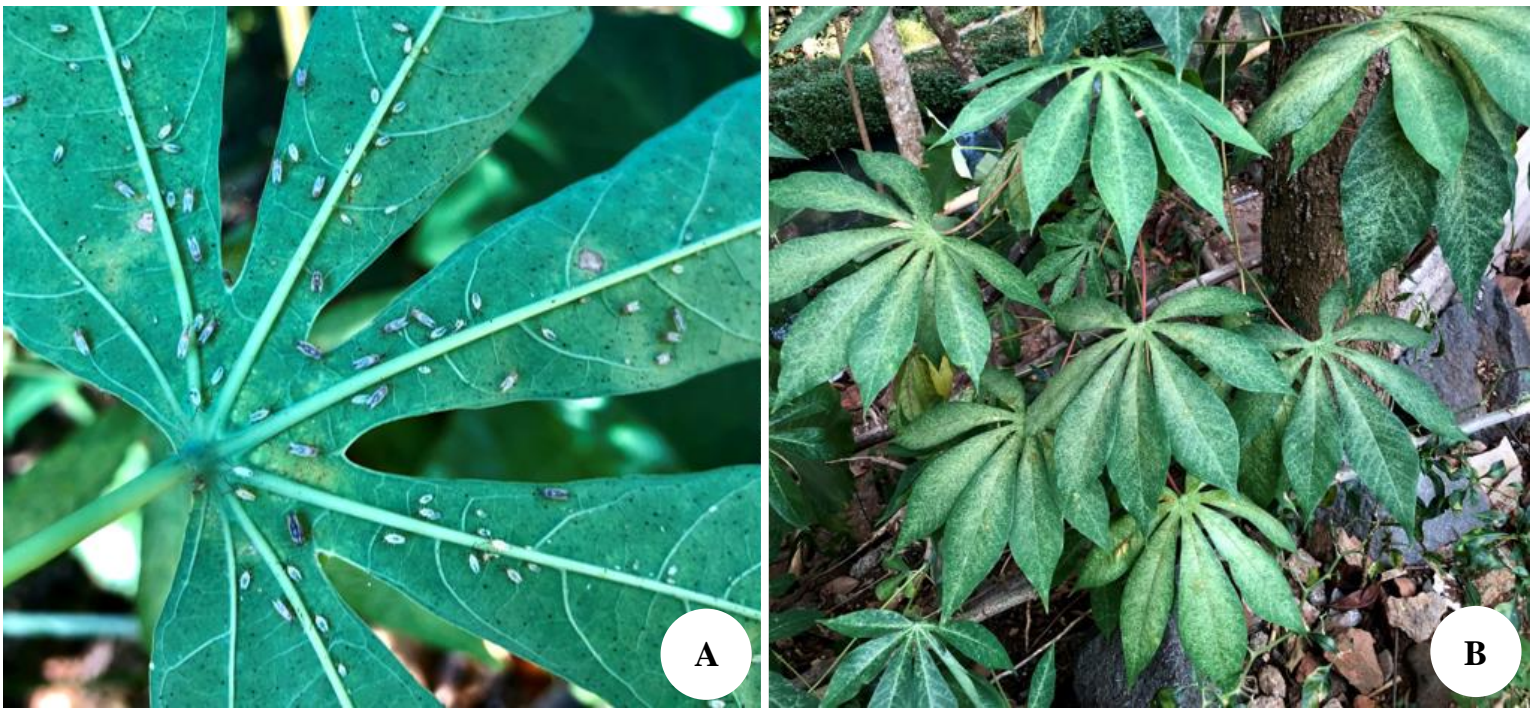

Figure 2. A colony of cassava lace bug on the lower surface of cassava leaf (A) and the respective infested plant with necrotic spots symptom on its leaves (B)

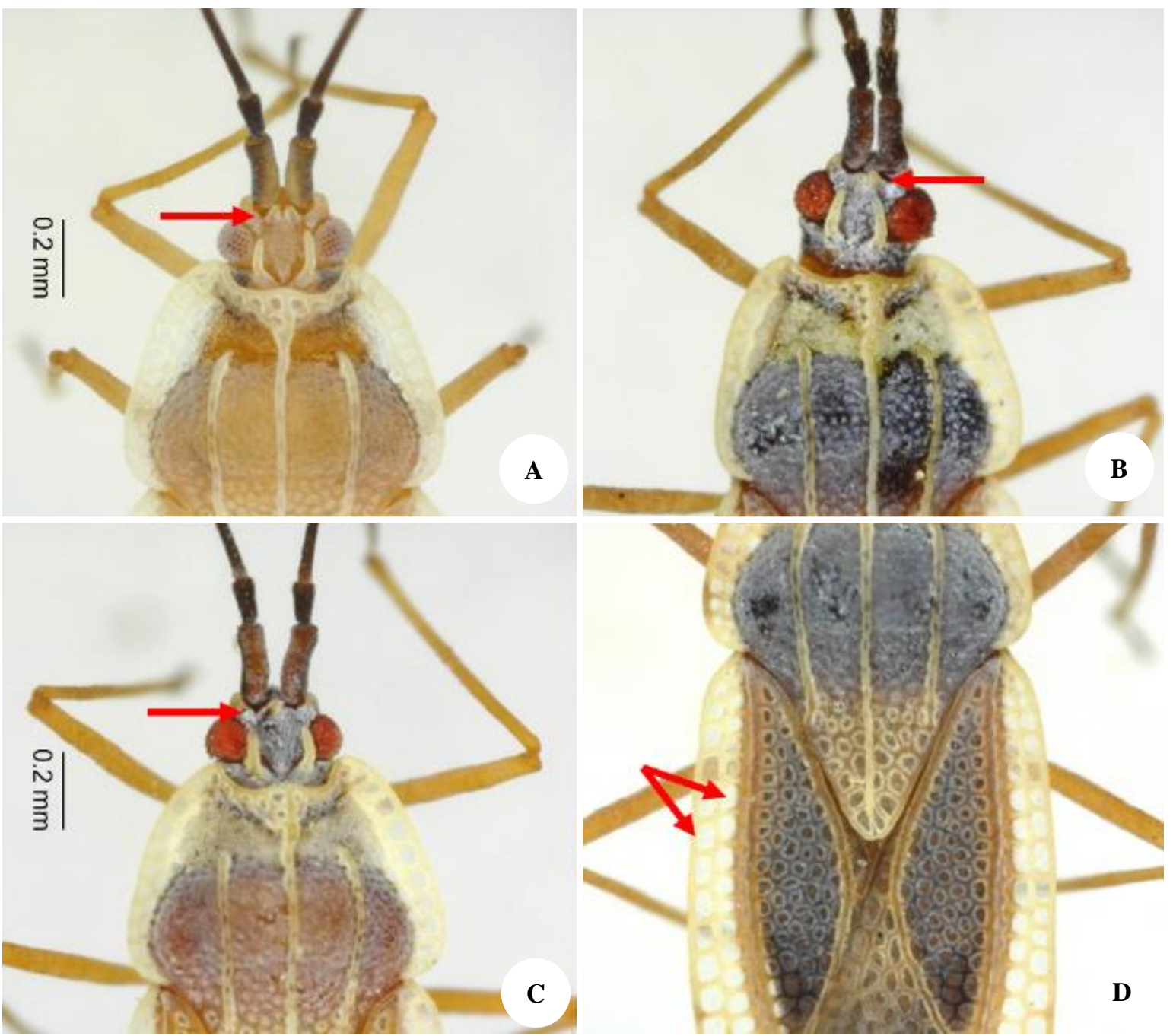

Figure 3. The diagnostic characters of Vatiga illudens dorsal view; head with a pair of frontal spines on the head (A); head lacking left frontal spine (B); head lacking right frontal spine (C); and dorsal view of hemelytra showing the costal area is regularly biseriate (D) (the microscope magnification used to capture the images are 220x) 
Based on the comparison of morphological characters, there are five nymphal instars of $V$. illudens. In general, the lace bug has an elongated body, four segmented antenna, red eyes, and two-segmented tarsi. The general color of nymphs is yellowish-white (Figure 4A-E). In second and third instar nymphs, the apical and basal parts of antennal segments III and IV are yellowish black, and the tarsi are pale brown (Figure 4B-C). Wing pad development started in the fourth instar nymph. The wing pads were more clearly visible in the fifth instar nymph, where they extended to the fifth abdominal segment. Exuviae remained adhered to the abaxial surface of leaves after each molt. The adult is yellowish-brown and the pronotum is fuscous (Figure 4.F-G). The adult female has a single groove along the midline of the ventral side of the apical part of the abdomen. There is no groove at the apical part of the abdomen in the adult male (Figure 5).

We were unable to observe the egg in this investigation because it is embedded in the leaf tissue by the female. To see the eggs, one must carefully dissect the leaf at a precise oviposition site (da Silva Wengrat et al. 2015). The measurements of the nymphs and adults of $V$. illudens are presented in Table 2. The obtained values are consistent with the original species description (Drake 1922).

\section{Future considerations}

Since a decade ago, $V$. illudens has been recognized as a devastating pest of cassava in the Neotropical Region, mainly in Brazil (Bellon et al. 2017; da Silva Wengrat 2020). However, V. illudens infestation has been progressively increasing outside its native range. Streito et al. (2012) suggested that phytosanitary measures are necessary to prevent the further distribution of the pest. The infestation of this pest could reduce the root yield of cassava ranging from 21 to 55\% (Fialho et al. 2009; Montemayor et al. 2015). We also frequently found predatory mites (Acari: Phytoseiidae) inhabiting the $V$. illudens-infested leaves during our observations. However, we could not unequivocally determine whether the mites are preying on the lace bugs or just co-existing in the same niche. A plethora of reports evidenced that several phytoseiids, mainly the type-III, have been known to prey on the immature stages of soft-bodied insect pests (McMurty et al. 2013; Lam et al. 2021; Nakai et al. 2021). Several lace bugs were also infected by an unidentified entomopathogenic fungus (Figure 6). Alves et al. (2012) reported an accidental natural infection of Beauveria bassiana (Bals.) Vuill. (Hypocreales: Cordycipitaceae) in $V$. manihotae and suggested that this entomopathogenic fungus may be used as potential biocontrol agents of the pest.
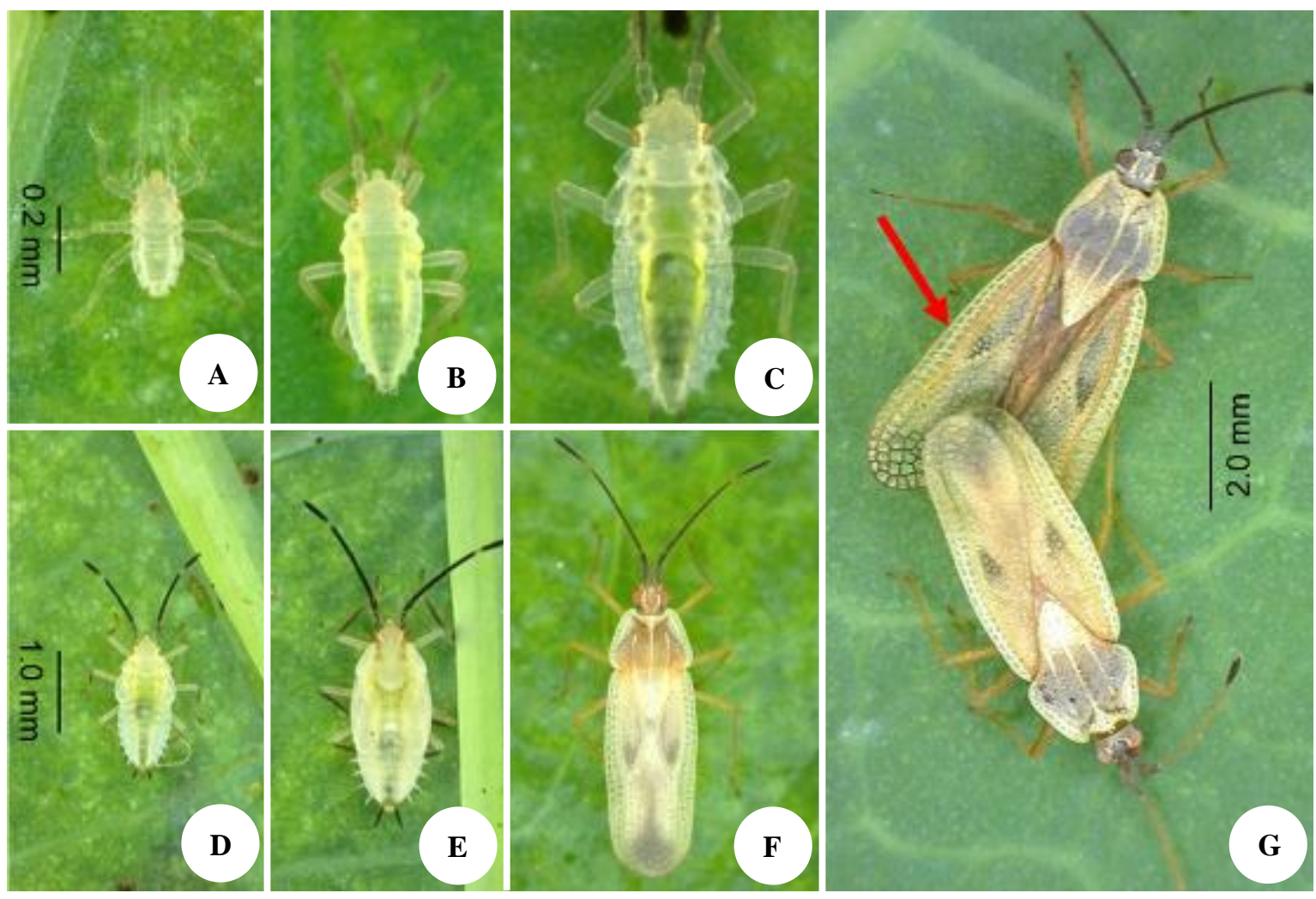

Figure 4. Living individuals of Vatiga illudens; first instar nymph (A); second instar nymph (B); third instar nymph (C); fourth instar nymph (E); fifth instar nymph (E); adult (F); and mating pair of adults (arrow indicates the lacy appearance of the adult dor sum) (G) (the microscope magnification used to capture the images are 220x (A-C), 55x (D-F), and 25x (G)) 
Table 2. Measurements in millimeters (mean \pm standard deviation) of the nymphs and adult of Vatiga illudens ( $n=10$ for each life stage)

\begin{tabular}{lcccccc}
\hline \multirow{2}{*}{ Measurements } & \multicolumn{5}{c}{ Nymphal stage } & \multirow{2}{*}{ Adult } \\
\cline { 2 - 6 } & 1st instar & 2nd instar & 3rd instar & 4th instar & 5th instar & \\
\hline Body length & $0.394 \pm 0.01$ & $0.664 \pm 0.02$ & $1.036 \pm 0.05$ & $1.287 \pm 0.01$ & $1.865 \pm 0.01$ & $2.957 \pm 0.08$ \\
Maximum width & $0.162 \pm 0.01$ & $0.273 \pm 0.01$ & $0.452 \pm 0.01$ & $0.627 \pm 0.01$ & $0.761 \pm 0.00$ & $0.902 \pm 0.04$ \\
\hline
\end{tabular}

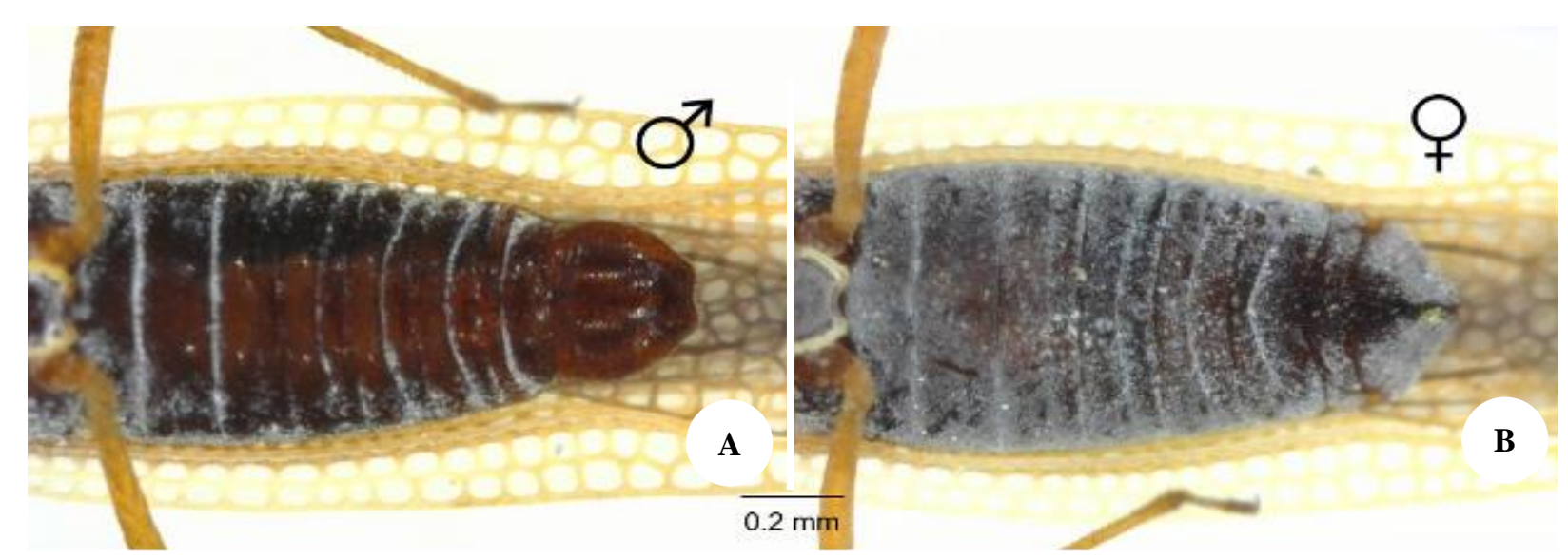

Figure 5. Body ventral side of adult male and female of Vatiga illudens showing the sexual dimorphic characters at the apical part of the abdomen (the microscope magnification used to capture the images are 220x)
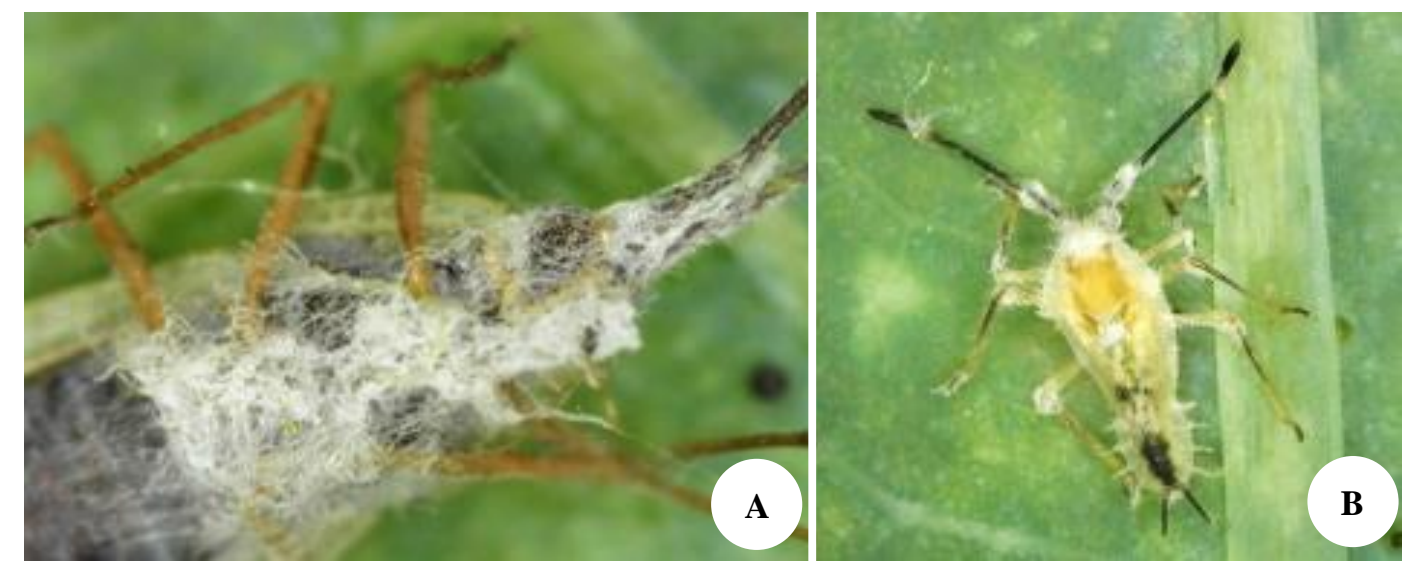

Figure 6. Habitus images of Vatiga illudens that are infected by an unidentified entomopathogenic fungus

Taking into account the outbreaks of the exotic $P$. manihoti Matile-Ferrero in Indonesia (Fanani et al. 2019; Supartha et al. 2020), we assume that $V$. illudens will also aggressively spread in other cassava productive sectors in Java. The lack of basic information on $V$. illudens, undoubtedly will complicate the assessment and prediction of the pest outbreak in Indonesia. Therefore, a more comprehensive study about its distribution and biology is urgently needed to anticipate its invasion and to develop proper control measures. Some aspects that must be studied for future research are (i) the exploration of the occurrence of CLB in other parts of Indonesia and the making of an accurate distribution-map of the pest, also a phylogeographic analysis can be conducted; (ii) the determination of the biological parameters of CLB found in Indonesia such as by a life-table analysis; (iii) the investigation of the association between CLB with native organisms in its distribution range in Indonesia, with the aim to list potential biocontrol agents; and lastly (iv) the evaluation of the resistance of local cassava genotypes or clones against CLB.

\section{ACKNOWLEDGEMENTS}

The authors would like to thank Alexander Harris Knudson (Department of Entomology, North Dakota State University, USA), Jun Souma (Entomological Laboratory, Kyushu University, Japan), and Sara I. Montemayor (División Entomología, Universidad Nacional de La Plata, Argentina) for their validation of the species identity. The authors would also like to offer special thanks to Jun 
Souma for the help in describing the diagnostic and sexual dimorphism characters of the species. Linguistic assistance provided by Shubhra Singh (Patanjali Research Institute, India) was greatly appreciated. We would like to thank the Indonesian Institute of Sciences for allowing the submission of specimens for the collection of the Museum Zoologicum Bogoriense. We would like to thank our colleagues Desy Setyoningrum, Fenesha Pratiwi, Indah Kumalasari, Mia Prastika Devi, Qurrota A'yuni Apriliana, and Mohammad Saifudin Afandi for their assistance during the field investigations.

\section{REFERENCES}

Alves LFA, Bellon PP, Rheinheimer AR, Pietrowski V. 2012. First record of Beauveria bassiana (Hyphomycetes: Moniliales) on adults of cassava lace bug Vatiga manihotae (Drake) (Hemiptera: Tingidae) in Brazil. Arq Inst Biol 79(2): 309-311. DOI: 10.1590/S180816572012000200024.

Bellon PP, da Silva Wengrat APG, Kassab SO, Pietrowski V, Loureiro ES. 2012. Occurrence of lace bug Vatiga illudens and Vatiga manihotae (Hemiptera: Tingidae) in Mato Grosso do Sul, Midwestern Brazil. An Acad Bras Ciên 84(3): 703-705. DOI: 10.1590/S000137652012000300012.

Bellon PP, de Oliveira HN, de Souza Loureiro E, Santana DRS, Otsubo AA, Mota TA. 2017. Populational fluctuation of lace bug in cassava. Arq Inst Biol 84: 1-6. DOI: 10.1590/1808-1657000602015.

Bellotti AC, Smith L, Lapointe SL. 1999. Recent advances in cassava pest management. Ann Rev Entomol 44: 343-370. DOI: 10.1146/annurev.ento.44.1.343.

Bellotti A, Campo BVH, Hyman G. 2012. Cassava production and pest management: Present and potential threats in a changing environment. Trop Plant Biol 5: 39-72. DOI:10.1007/s12042-011-9091-4.

Cho G, Kim W, Kwon YS, Lee S. 2020. Checklist of the lace bugs (Hemiptera: Tingidae) of Korea. J Asia-Pac Entomol 23: 736-745. DOI: 10.1016/j.aspen.2020.04.005

da Silva Wengrat APG, Barilli DR, Uemura-Lima DH, Gazola D, Guimarães ATB, Pietrowski V. 2020. Resistance of cassava genotypes to Vatiga manihotae (Drake 18992 (Hemiptera: Tingidae). Rev Bras Entomol 64(3): e20200017. DOI: 10.1590/1806-9665RBENT-2020-0017.

da Silva Wengrat APG, Matesco VC, Barão KR, Grazia J, Pietrowski V. 2015. External morphology of the immature stages of Vatiga manihotae (Hemiptera: Tingidae) with comments on ontogenesis. Fla Entomol 98(2): 626-632. DOI: 10.1653/024.098.0236.

dos Santos JKB, do Santos TT, Chagas AB, dos Santos E, de Souza AV, da Silva DJ, da Silvo Araujo A, Pinheiro RA, Barbosa JPF, das Neves JDS, da Silva Wengrat AP, de Barros RP. 2019. Correlation of climatic elements with phases of the lace bug Vatiga illudens (Hemiptera: Tingidae) in two cassava cultivars (Manihot esculenta Crantz, Euphorbiaceae). Afr J Agric Res 14(9): 559-564. DOI: 10.5897/AJAR2018.13780

Drake CJ. 1922. Neotropical Tingidae with descriptions of three new genera and thirty-two new species and varieties (Hemiptera). Mem Carnegie Mus 9: 351-378.

Drake CJ, Ruhoff FA. 1965. Lacebugs of the world: A catalog (Hemiptera: Tingidae). Bull US Natl Mus 243: 1-634. DOI: 10.5479/si.03629236.243.1.

Du S, Yao Y. 2018. A new genus and species of Tingidae (Heteroptera: Cimicomorpha) from Myanmar, with the analysis of the evolution of hood, carinae and paranota. Zool Syst 43(3): 283-293. DOI: 10.11865/zs.201828.

Fanani MZ, Rauf A, Maryana N, Nurmansyah A, Hindayana D. 2019 Geographic distribution of the invasive mealybug Phenacoccus manihoti and its introduced parasitoid Anagyrus lopezi in parts of Indonesia. Biodiversitas 20: 3751-3757. DOI: 10.13057/biodiv/d201238.

Fialho J, Vieira EA, Paula-Moraes SV, Junquiera NTV. 2009. Economic damage caused by lacebug upon cassava root and foliage yield. Sci Agrar 10: 151-155. DOI: 10.5380/rsa.v10i2.13587.
Froeschner RC. 1993. The neotropical lace bugs of the genus Vatiga (Heteroptera: Tingidae), pests of cassava: New synonymies and key to species. Proc Biol Soc Wash 95: 457-462.

Guidoti M, Montemayor SI, Guilbert É. 2015. Lace bugs (Tingidae). In: Panizzi A, Gracia J (eds). True Bugs (Heteroptera) of the Neotropica. Entomology in Focus, vol. 2. Springer, Dordrecht. DOI: 10.1007/97894-017-9861-7_14.

Guilbert E. 2001. Phylogeny and evolution of exaggerated traits among the Tingidae (Heteroptera, Cimicomorpha). Zool Scr 30: 313-324. DOI: 10.1046/j.1463-6409.2001.00069.x.

Halbert S. 2010. The cassava lace bug, Vatiga illudens (Drake) (Hemiptera: Tingidae), a new exotic lace bug in Florida. Florida Division of Plant Industry, Pest Alert 1-2. Available online at http://www.freshfromflorida.com/DivisionsOffices/PlantIndustry/Plant-Industry-Publications/PestAlerts/Cassava-Lace-Bug

Kalshoven LGE. 1981. The Pests of Crops in Indonesia. Revised by Van der Laan PA. P.T. Ichitar Baru - Van Hoeve, Jakarta.

Lam W, Paynter Q, Zhang ZQ. 2021. Functional response of Amblyseius herbicolus (Acari: Phytoseiidae) on Sericothrips staphylinus (Thysanoptera: Thripidae), an ineffective biocontrol agent of gorse. Biol Control 152: 104468. DOI: 10.1016/j.biocontrol.2020.104468.

McMurty JA, de Moraes GJ, Sourassou NF. 2013. Revision of the lifestyles of phytoseiid mites (Acari: Phytoseiidae) and implications for biological control strategies. Syst Appl Acarol 18(4): 297-320. DOI: $10.11158 /$ saa.18.4.1

Ministry of Agriculture of Indonesia. 2020. The Government Regulation of the Republic of Indonesia number 25 of 2020 Concerning Plant Quarantine.

Montemayor, SI, Dellapé PM, Melo MC. 2015. Predicting the potential invasion suitability of regions to cassava lace bug pests (Heteroptera: Tingidae: Vatiga spp.). Bull Entomol Res 105(2): 173-181. DOI: 10.1017/S0007485314000856.

Muniappan R, Shepard BM, Watson GW, Carner GR, Rauf A, Sartiani D, Hidayat P, Afun JVK, Goergen G, Ziaur Rahman AKM. 2009. New records of invasive insects (Hemiptera: Sternorrhyncha) in Southeast Asia and West Africa. J Agr Urban Entomol 26(4): 167-174. DOI: 10.3954/1523-5475-26.4.167.

Nakai Z, Shimizu K, Oida H, Sonoda S. 2021. Host plant and humidity effects on phytoseiid mite, Gynaeseius liturivorus (Acari: Phytoseiidae) egg hatchability. Exp Appl Acarol 84: 135-147. DOI: 10.1007/s10493-021-00617-3.

Puspitarini RD, Fernando I, Rachmawati R, Hadi MS, Rizali A. 2021. Host plant variability affects the development and reproduction of Tetranychus urticae. Int J Acarol DOI: 10.1080/01647954.2021.1915377.

Saleh N, Rahayu M, Indiati SW, Radjit BS, Wahyuningsih S. 2013. Pests, Diseases, and Weeds on Cassava Plants. IAARD Press, Jakarta. In Indonesian

Schuh RT, Weirauch C. 2020. True Bugs of the World (Hemiptera: Heteroptera): Classification and Natural History, 2nd ed. Siri Scientific Press, Manchester.

Shorthouse DP. 2010. SimpleMappr, an online tool to produce publication-quality point maps. [accessed 10 June 2021]. https://www.simplemappr.net/

Souma J. 2020. Discoveries of the genera Baeochila and Idiocysta from Japan, with descriptions of two new species (Hemiptera: Heteroptera: Tingidae). Zootaxa 4731(3): 388-402. DOI: 10.11646/zootaxa.4731.3.7.

Souma J, Kamitani S. 2021. Taxonomic review of the lace bug genus Omoplax (Hemiptera: Heteroptera: Tingidae) endemic to "Oriental Galapagos" (the Ogasawara Islands, Japan) with the descriptions of its new allied genus and species. Entomol Sci 24: 3-11. DOI: 10.1111/ens. 12445 .

Stonedahl GM, Dolling WR, duHeaume GJ. 1992. Identification guide to common tingid pests of the world (Heteroptera: Tingidae). Trop Pest Manag 38(4): 438-449. DOI: 10.1080/09670879209371743.

Streito JC, Guilbert E, Mérion S, Minatchy J, Pastou D. 2012. Premier signalement de Vatiga illudens (Drake, 1992) nouveau ravageur du Manioc dans le Mascareignes (Hemiptera Tingidae). L'Entomologiste 68: 357-360. In French

Supartha IW, Yudha IKW, Wiradana PA, Susial IW. 2020. Response of parasitoids to invasive pest Phenacoccus manihoti Matile-Ferrero (Hemiptera: Pseudococcidae) on cassava crop in Bali, Indonesia. Biodiversitas 21: 4543-4549. DOI: 10.13057/biodiv/d211011. 